\title{
The effects of different dietary contents of protein on amino acid and glucose production and on the contribution of amino acids to gluconeogenesis in sheep
}

\author{
BY P. E. B. REILLY \\ Department of Biochemistry, The University, PO Box 147, Liverpool \\ $L 693^{B} X$ \\ AND E. J. H. FORD \\ Department of Veterinary Clinical Studies, University of Liverpool \\ Veterinary Field Station, Leahurst, Neston, Cheshire
}

(Received 20 October 1970-Accepted 12 March 1971)

\begin{abstract}
I. Free amino acid entry rates, rates of portal uptake of amino acids and rates of glucose synthesis from amino acids have been measured during the continuous intravenous infusion of $\left[\mathrm{U}-{ }^{14} \mathrm{C}\right]$-labelled mixed amino acids in six sheep receiving diets that supplied different amounts of protein.

2. In four of these sheep and in one other, total rates of glucose production have been measured using continuous intravenous infusions of $\left[\mathrm{U}-{ }^{14} \mathrm{C}\right]-l a b e l l e d$ glucose.

3. A significant correlation was found between total amino acid entry rate $(Y \mathrm{mg} / \mathrm{min} . \mathrm{kg})$ and daily protein intake $(X \mathrm{~g} / \mathrm{kg}): Y=2.14+\mathrm{I} \cdot 38 X(r=0.878,0.02>P>0.0 \mathrm{I})$.

4. A significant correlation was found between the rate of absorption of amino acids into the portal system $(Y \mathrm{mg} / \mathrm{min} . \mathrm{kg})$ and the daily protein intake $(X \mathrm{~g} / \mathrm{kg}): Y=0.5^{8}+0.58 X$ $(r=0.884,0.02>P>0.01)$.

5. A highly significant correlation was found between total glucose production rates ( $Y \mathrm{mg} / \mathrm{min} . \mathrm{kg}$ ) and daily protein intake $(X \mathrm{~g} / \mathrm{kg})$ :
\end{abstract}

$$
Y=0.375+0.702 X \quad(r=0.866,0.005>P>0.001) \text {. }
$$

6. The mean proportional contribution to total amino acid entry made by portal absorption was $33 \cdot 5 \pm \mathrm{I} \cdot 8 \%$ (six animals).

7. A significant correlation was found between the rate of glucose production from amino acids $(Y \mathrm{mg} / \mathrm{min} . \mathrm{kg})$ and the rate of entry of amino acids $(X \mathrm{mg} / \mathrm{min} . \mathrm{kg})$ :

$$
Y=0.189 X-0.414 \quad(r=0.84,0.01>P>0.005) \text {. }
$$

8. The best approximation of the proportion of glucose derived from amino acids was $28 \cdot 16 \pm 5 \cdot x \%$ (six animals).

9. The specific radioactivities of amino acids in liver, kidney and muscle did not approach those found in plasma during infusions of $\left[\mathrm{U}-{ }^{14} \mathrm{C}\right]$-labelled mixed amino acids of up to $6.75 \mathrm{~h}$.

Many studies of metabolite production have been made by the continuous infusion dilution method, e.g. Annison \& White (1961), Bergman (1963), Ford (1963), Lindsay \& Ford (1964), Bergman, Roe \& Kon (1966), Leng, Steel \& Luick ( 1967 ) and Annison, Brown, Leng, Lindsay \& West ( 1967 ). This method is based on the concept that there is a homogeneous body pool of a metabolite and that mixed venous plasma is representative of this pool. The attainment, during the course of the infusion, of a plateau value for specific radioactivity of the metabolite in plasma is regarded as evidence that the rate of removal of radioactivity from the pool is equal to the rate of its addition. 
This enables the entry of the metabolite to be calculated (Steele, Wall, de Bodo \& Altszuler, 1956).

We have previously used the method (Ford \& Reilly, 1969, 1970) to measure the production rate of free amino acids and glucose, their oxidation to carbon dioxide and the rate of production of glucose from amino acids. Like other workers, we derived our results from plateau activities of free amino acids and of glucose in jugular plasma. It may be, however, that specific activities of metabolites in the tissues where conversion occurs, i.e. the liver and kidney for glucose production from free amino acids (Krebs, 1964), are not the same as in jugular plasma, so that conversion rates calculated from specific activities in jugular plasma will be inaccurate.

Such a situation is to be expected with metabolites, such as amino acids, which are absorbed in appreciable amounts from the alimentary tract. As a result of this continuous absorption of unlabelled material, specific radioactivities in portal plasma and hence in liver tissue are likely to be appreciably less than in the rest of the amino acid pool. In addition, endogenous production of amino acids from protein turn-over will cause the specific radioactivity of amino acids to be less in all cells than in extracellular fluid.

For these reasons, we wished to investigate further the relationships between the concentrations and specific activities of amino acids and glucose in tissues and plasma and to assess thereby the validity of the assumptions on which previous work by ourselves and others had been based. During continuous infusions lasting for up to $6.75 \mathrm{~h}$ after a priming dose, plateau specific activities of free amino acids and glucose in carotid, jugular and portal plasma were measured and compared with specific activities of these metabolites in samples of liver, kidney and muscle which had been removed immediately the infusions ceased.

\section{EXPERIMENTAL}

\section{Animals}

Seven female Clun Forest Sheep which had been reared on the Field Station were used. Two of them were $\mathrm{I} \cdot 5$ years old and were fed $1000 \mathrm{~g}$ hay/d. Five were about $\mathrm{I}$ year old and received either $800 \mathrm{~g}$ hay or $600 \mathrm{~g}$ grass nuts daily. These diets provided daily crude protein intakes ranging from 0.885 to $2.6 \mathrm{~g} / \mathrm{kg}$ body-weight. Details for individual sheep are given in Table $\mathbf{I}$.

The sheep were fed twice daily at 9.00 and $\mathrm{I} 7.00$ hours and all infusions were commenced about $2 \mathrm{~h}$ after the morning feed had been given. Using the terminology of Annison et al. ( 1967 ), these sheep would be described as ' $\mathrm{fed}$ '. The sheep maintained constant weight and were trained to stand quietly in stocks where the infusions were carried out. Approximately 6 weeks before infusion, the animals were anaesthetized and a length of the right carotid artery was exteriorized and incorporated within a skinfold to facilitate sampling of arterial blood. At a second operation a polyethylene cannula was introduced into a mesenteric vein and passed on to lie in the portal vein with its tip at the porta hepatis. The cannula was filled with $0.9 \%$ saline containing heparin $(20$ units $/ \mathrm{ml})$ and its other end, fitted with a polyethylene tap, was brought to the exterior and positioned on the abdominal wall with adhesive bandage. When the 
animal had fully recovered from this operation and appetite was normal, the radioactive amino acids were infused. Before each infusion a polyethylene cannula was inserted caudally under local anaesthesia, into each jugular vein and one of slightly smaller diameter was similarly inserted into the exteriorized right carotid artery.

\section{Infusion procedure}

Six sheep, nos. 2, 7, 22, 63, 64 and 66, were each given an infusion via the left jugular catheter of $\left[\mathrm{U}-{ }^{14} \mathrm{C}\right]$-labelled mixed amino acids (CFB r04; Radiochemical Centre, Amersham).

All the amino acid infusions were preceded by a priming dose of $5 \circ \mu \mathrm{Ci}$ of the labelled amino acid mixture. These infusions were given at the rate of $2 \mathrm{ml}$ (about $800 \mathrm{nCi}$ )/ min for periods varying from 180 to $405 \mathrm{~min}$. The labelled amino acids were dissolved in $0.9 \%$ saline buffered at $\mathrm{pH} 7.0$, containing $40 \mu \mathrm{g} / \mathrm{ml}$ of a mixture of eighteen amino acids in the proportions found in sheep plasma (Leibholz, 1965; Slater, 1965). All infusions were given by a peristaltic pump (Watson Marlow flow inducer).

Two weeks previously five sheep (nos. 65, 7, 66, 22 and 64) had been infused with $\left[\mathrm{U}-{ }^{14} \mathrm{C}\right]$-labelled glucose. Each of these infusions was preceded by the rapid injection of a priming dose ( $10 \mu \mathrm{Ci}$ ) and consisted of $40 \mu \mathrm{Ci}$ of the labelled glucose in $0.9 \%$ saline buffered to $\mathrm{pH} 7$ and contained $150 \mu \mathrm{g} / \mathrm{ml}$ glucose $(\mathrm{w} / \mathrm{v})$. This solution was infused over about $180 \mathrm{~min}$ at the rate of about $2 \mathrm{ml}$ (i.e. $200 \mathrm{nCi}$ )/min. In all instances, the weights of carrier material infused were insignificant in relation to entry rates.

\section{Sampling procedures}

During glucose infusions the blood samples ( ${ }_{5} \mathrm{ml}$ ) were withdrawn with a syringe from carotid and jugular catheters. During the amino acid infusions the blood samples $(20 \mathrm{ml})$ were withdrawn from carotid, jugular and portal catheters. All samples were mixed with $5 \mathrm{mg}$ sodium fluoride and $25^{\circ}$ units heparin, centrifuged at $4^{\circ}$ within $3 \circ \mathrm{min}$ of collection, and the plasma was stored at $-20^{\circ}$ until analysed. Each sheep, with the exception of no. 65, was killed as soon as its amino acid infusion had ended, by the rapid injection of a lethal dose of sodium pentabarbitone into the arterial catheter. Death was instantaneous and the carcass was immediately opened and samples of liver, kidney and vastus muscle were removed and placed in liquid nitrogen.

\section{Chemical methods}

The free amino acid fraction was separated from the other constituents of plasma by a modification of the method of Harris, Tigane \& Hanes (1961). Details of the method and the results of recovery trials are given by Ford \& Reilly ( 1969$)$. The amino nitrogen content of a portion of the sample was measured by the ninhydrin method of Rosen (1957) calibrated with known weights of the same mixture of eighteen amino acids as was used in the infusions and also with weighed amounts of the amino acid fraction of sheep plasma. Since the colour yields for the same weights of amino acids in both the mixture and the plasma amino acid fraction were similar, the total weights of free amino acids in plasma were calculated directly from extinctions at $570 \mathrm{~nm}$. 
A portion of the amino acid fraction was added to $10 \mathrm{ml}$ of scintillation fluid (Hall \& Cocking, I965) and counted in a Beckman LS $200 \mathrm{~B}$ scintillation counter.

Suitable dilutions of infusion fluid were added to pre-infusion samples of plasma, and the free amino acid fraction was separated and assayed for radioactivity as described above with an efficiency of about $80 \%$.

The carbon content of the amino acid fraction was determined by combustion of weighed amounts of the dried material from the ion-exchange columns.

Homogenates $(10 \%, \mathrm{w} / \mathrm{v})$ of the frozen tissue samples were made in cold $10 \%(\mathrm{w} / \mathrm{v})$ trichloroacetic acid with an Ultraturrax tissue grinder (Janke \& Kunkel KG.). The free amino acid fraction of the supernatant liquid, obtained by centrifugation of the homogenate at $1000 \times \mathbf{g}$ for $\mathrm{I}_{5} \mathrm{~min}$, was separated from other constituents by the method described for plasma. The amino acid concentration and radioactivity were measured as described for plasma, and the specific radioactivity of the free amino acids in tissues was calculated.

\section{Plasma glucose}

Plasma was deproteinized with $0.3 \mathrm{~N}$-barium hydroxide and $5 \%(\mathrm{w} / \mathrm{v})$ zinc sulphate and the glucose in the filtrate determined by the enzyme method of Huggett \& Nixon (1957). Carrier glucose was added to deproteinized filtrates of plasma and the solution evaporated to dryness under reduced pressure. The residue was extracted three times with hot $90 \%(\mathrm{v} / \mathrm{v})$ methanol, and glucose pentaacetate was prepared and recrystallized as described by Jones ( I $^{6} 6_{5}$ ). The dried and weighed samples of glucose pentaacetate were dissolved in toluene and added to the scintillation fluid described by Hall $\&$ Cocking $(1965)$. The radioactivity of the pentaacetate was measured in a refrigerated scintillation counter (Panax Ltd, Redhill, Surrey). Dilutions of infusion fluid were added to pre-infusion plasma samples and the glucose pentaacetate prepared from this plasma was assayed for radioactivity in the same manner at an efficiency of $60 \%$.

\section{Tissue glucose}

The homogenates of liver, kidney and muscle samples were made in distilled water containing $0.02 \%(\mathrm{w} / \mathrm{v})$ sodium fluoride, and after centrifugation at $1000 \times \mathrm{g}$ for I 5 min were treated in the same manner as plasma to determine the concentration and specific radioactivity of glucose.

\section{RESULTS}

Table I gives the age, weight and diet of the sheep used for the amino acid infusions, and Table 2 gives the concentration of glucose and of free amino acids in their carotid, jugular and portal plasmas and the concentrations of free amino acids in the samples of liver, kidney, and muscle.

In all animals glucose concentrations in plasma from the three sites were similar, whereas the concentrations of free amino acids were always higher in portal plasma samples than in carotid and jugular plasma samples. This would be the result of the absorption of free amino acids from the gastro-intestinal tract, but without knowing the flow-rates of portal blood it is not possible to calculate rates of absorption from these concentrations. 
Table 3 gives the results obtained during the constant infusion of [U-14 C]-labelled mixed amino acids for periods of up to $6.75 \mathrm{~h}$. In all sheep, concentrations of amino acids and glucose were constant throughout the infusion periods and plateau values for specific activities of amino acids and glucose were reached from about $150 \mathrm{~min}$ onwards. The values in columns 4 and 5 are means of all measurements made from

Table I. Characteristics of the seven sheep used for the amino acid and glucose infusions

\begin{tabular}{|c|c|c|c|c|}
\hline \multirow[b]{2}{*}{ Sheep no. } & \multirow{2}{*}{$\begin{array}{l}\text { Weight } \\
(\mathrm{kg})\end{array}$} & \multicolumn{2}{|c|}{ Diet } & \multirow{2}{*}{$\begin{array}{l}\text { Crude protein } \\
(\mathrm{g} / \mathrm{kg} \cdot \mathrm{d})\end{array}$} \\
\hline & & Type & $(g / d)$ & \\
\hline 63 & 62 & Hay & 1000 & 0.885 \\
\hline 7 & 38 & Hay & 800 & $I \cdot 16$ \\
\hline 2 & $45 \cdot 5$ & Hay & 1000 & $I \cdot 2 I$ \\
\hline 66 & 32 & Hay & 800 & $1 \cdot 37$ \\
\hline 65 & 35 & Hay & 800 & $1 \cdot 40$ \\
\hline 22 & 34.5 & Grass nuts & 600 & $2 \cdot 54$ \\
\hline 64 & 33.5 & Grass nuts & 600 & 2.60 \\
\hline
\end{tabular}

Sheep 2 and 63 were 1.5 years old; the others were I year old.

Table 2. Concentrations of amino acids and glucose in plasma, and amino acids in tissues in the six sheep used for the amino acid infusions

\begin{tabular}{|c|c|c|c|c|c|}
\hline \multirow{2}{*}{$\begin{array}{c}\text { Sheep } \\
\text { no. } \\
63\end{array}$} & \multicolumn{2}{|c|}{$\begin{array}{l}\text { Plasma amino acid concentration } \\
\qquad(\mathrm{mg} / 100 \mathrm{ml})\end{array}$} & \multirow{2}{*}{$\begin{array}{c}\text { Plasma glucose } \\
\text { concentration } \\
(\mathrm{mg} / \text { roo ml) } \\
53.5 \pm 0.01(7) \\
53.0 \pm 0.01(7) \\
53.0 \pm 0.01(7)\end{array}$} & \multicolumn{2}{|c|}{$\begin{array}{c}\text { Tissue amino acid } \\
\text { concentration }(\mathrm{mg} / \mathrm{ro0} \mathrm{g})\end{array}$} \\
\hline & $\begin{array}{l}\text { Carotid } \\
\text { Jugular } \\
\text { Portal }\end{array}$ & $\begin{array}{l}35 \cdot 9 \pm 0 \cdot 9(7) \\
35 \cdot 4 \pm x \cdot 3(6) \\
38 \cdot 9 \pm \mathrm{I} \cdot 0(7)\end{array}$ & & $\begin{array}{l}\text { Liver } \\
\text { Kidney } \\
\text { Muscle }\end{array}$ & $\begin{array}{l}204 \cdot 6 \\
286 \cdot 4 \\
157 \cdot 0\end{array}$ \\
\hline 7 & $\begin{array}{l}\text { Carotid } \\
\text { Jugular } \\
\text { Portal }\end{array}$ & $\begin{array}{l}43 \cdot 6 \pm 1 \cdot 4(7) \\
43 \cdot 3 \pm I \cdot 8(7) \\
46 \cdot 5 \pm 1 \cdot 2(6)\end{array}$ & $\begin{array}{l}73 \cdot 6 \pm 1 \cdot 2(8) \\
72 \cdot 3 \pm x \cdot 7(8) \\
72 \cdot 3 \pm 0 \cdot 9(7)\end{array}$ & $\begin{array}{l}\text { Liver } \\
\text { Kidney } \\
\text { Muscle }\end{array}$ & $\begin{array}{l}243 \cdot 8 \\
279 \cdot 2 \\
153 \cdot 0\end{array}$ \\
\hline 2 & $\begin{array}{l}\text { Carotid } \\
\text { Jugular } \\
\text { Portal }\end{array}$ & $\begin{array}{l}30.7 \pm 0.95(7) \\
30.3 \pm 0.56(7) \\
34.3 \pm 0.51(7)\end{array}$ & $\begin{array}{l}58 \cdot 2 \pm 0.01(7) \\
59 \cdot 5 \pm 0.04(6) \\
58 \cdot 5 \pm 0.01(7)\end{array}$ & $\begin{array}{l}\text { Liver } \\
\text { Kidney } \\
\text { Muscle }\end{array}$ & $\begin{array}{l}256 \cdot 5 \\
306 \cdot 0 \\
183 \cdot 0\end{array}$ \\
\hline 66 & $\begin{array}{l}\text { Carotid } \\
\text { Jugular } \\
\text { Portal }\end{array}$ & $\begin{array}{l}26.6 \pm 0.7(5) \\
26.1 \pm 0.2(4) \\
29.7 \pm 0.7(5)\end{array}$ & $\begin{array}{l}52 \cdot 2 \pm 0.02(5) \\
5 I \cdot 5 \pm 0.02(6) \\
5 I \cdot 0 \pm 0.01(5)\end{array}$ & $\begin{array}{l}\text { Liver } \\
\text { Kidney } \\
\text { Muscle }\end{array}$ & $\begin{array}{l}210 \cdot 0 \\
338 \cdot 0 \\
150 \cdot 0\end{array}$ \\
\hline 22 & $\begin{array}{l}\text { Carotid } \\
\text { Jugular } \\
\text { Portal }\end{array}$ & $\begin{array}{l}4 I \cdot I \pm 2 \cdot 3(6) \\
40 \cdot 6 \pm 1 \cdot 9(6) \\
50 \cdot 8 \pm 2 \cdot 3(6)\end{array}$ & $\begin{array}{l}74 \cdot 0 \pm 0.06(6) \\
70.5 \pm 0.1(6) \\
70.5 \pm 0.3(6)\end{array}$ & $\begin{array}{l}\text { Liver } \\
\text { Kidney } \\
\text { Muscle }\end{array}$ & $\begin{array}{l}242 \cdot 0 \\
292 \cdot 0 \\
185.5\end{array}$ \\
\hline 64 & $\begin{array}{l}\text { Carotid } \\
\text { Jugular } \\
\text { Portal }\end{array}$ & $\begin{array}{l}57 \cdot 4 \pm 0.7(6) \\
54.4 \pm 0.6(6) \\
72 \cdot 6 \pm 1 \cdot 2(6)\end{array}$ & $\begin{array}{l}51.7 \pm 0.01(5) \\
53.8 \pm 0.01(5) \\
53.0 \pm 0.01(5)\end{array}$ & $\begin{array}{l}\text { Liver } \\
\text { Kidney } \\
\text { Muscle }\end{array}$ & $\begin{array}{l}253 \cdot 0 \\
274 \cdot 0 \\
198 \cdot 0\end{array}$ \\
\hline
\end{tabular}

150 min until the end of infusion. Column 5 shows that glucose specific activity was similar in carotid, portal and jugular plasma in all animals. There were, however, differences between specific activities of the amino acids at the three sites, which proved to be statistically significant when comparisons were made by the paired $t$ test. The carotid (C) value was always higher than the jugular $(\mathrm{J})(P<0.0 \mathrm{I})$ and the portal $(\mathrm{P})$ lower than the jugular $(P<0.00 \mathrm{I})$. The mean differences with their standard errors were: $(\mathrm{C}-\mathrm{J}) \mathrm{I} \cdot 07 \pm 0.20,(\mathrm{C}-\mathrm{P}) 2 \cdot 83 \pm 0.42,(\mathrm{~J}-\mathrm{P}) \mathrm{I} \cdot 77 \pm 0.25$. 
In most of the published work on the use of isotope dilution techniques to measure entry rates of constituents of the body pool, jugular plasma has been taken as representative of the plasma compartment. Mixing of the venous return takes place in the right side of the heart so that mixed venous plasma is present in the pulmonary artery. Unfortunately, this vessel is not readily accessible but, if it is assumed that addition of unlabelled metabolite by the lung is negligible compared with that by other body tissues, then the specific activity of a labelled metabolite in arterial, i.e. carotid, plasma should be the best estimate of the true specific activity of mixed plasma. The present results indicate that the tissues of the head and neck contribute unlabelled amino acids to the plasma as it passes from carotid artery to jugular vein.

Table 3. Specific activities of plasma constituents and entry rates of amino acids in six sheep given diets of different protein content during constant infusion of $\left[U-{ }^{14} C\right]-$ labelled mixed amino acids

\begin{tabular}{|c|c|c|c|c|c|c|c|}
\hline \multirow{3}{*}{$\begin{array}{l}\text { Sheep } \\
\text { no. }\end{array}$} & \multirow{3}{*}{$\begin{array}{c}\text { Infusion } \\
\text { rate } \\
\text { (nCi/min) }\end{array}$} & \multirow{2}{*}{\multicolumn{3}{|c|}{$\begin{array}{l}\text { Mean specific activity in plasma } \\
\text { (nCi/mg C) }\end{array}$}} & \multicolumn{3}{|c|}{ Entry rates of amino acids } \\
\hline & & & & & & & $\mathrm{mg}$ amino \\
\hline & & & Amino acids & Glucose & & $\mathrm{mg} \mathrm{C} / \mathrm{min}$ & $\mathrm{min} \cdot \mathrm{kg}$ \\
\hline 63 & 600 & $\begin{array}{l}\text { Carotid } \\
\text { Jugular } \\
\text { Portal }\end{array}$ & $\begin{array}{l}5 \cdot 1 \\
4 \cdot 5 \\
3 \cdot 8\end{array}$ & $\begin{array}{l}I \cdot 7 \\
I \cdot 6 \\
I \cdot 6\end{array}$ & $\begin{array}{l}\text { Total entry } \\
\text { Head entry } \\
\text { Portal uptake }\end{array}$ & $\begin{array}{r}116.0 \\
18.0 \\
41.0\end{array}$ & $\frac{4 \cdot 1}{1 \cdot 46}$ \\
\hline 7 & 900 & $\begin{array}{l}\text { Carotid } \\
\text { Jugular } \\
\text { Portal }\end{array}$ & $\begin{array}{l}16 \cdot 4 \\
14.5 \\
12.0\end{array}$ & $\begin{array}{l}I \cdot 9 \\
I \cdot 9 \\
I \cdot 9\end{array}$ & $\begin{array}{l}\text { Total entry } \\
\text { Head entry } \\
\text { Portal uptake }\end{array}$ & $\begin{array}{r}55^{\circ} \circ \\
7 \cdot 0 \\
20 \cdot 0\end{array}$ & $\frac{2 \cdot 9}{I \cdot I 6}$ \\
\hline 2 & 925 & $\begin{array}{l}\text { Carotid } \\
\text { Jugular } \\
\text { Portal }\end{array}$ & $\begin{array}{r}12.0 \\
10.7 \\
9.0\end{array}$ & $\begin{array}{l}2 \cdot 6 \\
2 \cdot 6 \\
2 \cdot 6\end{array}$ & $\begin{array}{l}\text { Total entry } \\
\text { Head entry } \\
\text { Portal uptake }\end{array}$ & $\begin{array}{r}77 \cdot 0 \\
9.0 \\
26 \cdot 0\end{array}$ & $\frac{4 \cdot I}{I \cdot 26}$ \\
\hline 66 & 825 & $\begin{array}{l}\text { Carotid } \\
\text { Jugular } \\
\text { Portal }\end{array}$ & $\begin{array}{l}15 \cdot 4 \\
14.2 \\
12.0\end{array}$ & $\begin{array}{l}3 \cdot 7 \\
3 \cdot 6 \\
3 \cdot 8\end{array}$ & $\begin{array}{l}\text { Total entry } \\
\text { Head entry } \\
\text { Portal uptake }\end{array}$ & $\begin{array}{r}53 \cdot 5 \\
4.5 \\
14.5\end{array}$ & $\frac{3.7}{1 \cdot 05}$ \\
\hline 22 & 920 & $\begin{array}{l}\text { Carotid } \\
\text { Jugular } \\
\text { Portal }\end{array}$ & $\begin{array}{l}9 \cdot 9 \\
9 \cdot 2 \\
7 \cdot 4\end{array}$ & $\begin{array}{l}2 \cdot 8 \\
2 \cdot 9 \\
2 \cdot 9\end{array}$ & $\begin{array}{l}\text { Total entry } \\
\text { Head entry } \\
\text { Portal uptake }\end{array}$ & $\begin{array}{r}92 \cdot 5 \\
8 \cdot 5 \\
32 * 5\end{array}$ & $\frac{6 \cdot 0}{2 \cdot 2}$ \\
\hline 64 & 680 & $\begin{array}{l}\text { Carotid } \\
\text { Jugular } \\
\text { Portal }\end{array}$ & $\begin{array}{l}8 \cdot 0 \\
7 \cdot 4 \\
5 \cdot 7\end{array}$ & $\begin{array}{l}3 \cdot 9 \\
3 \cdot 8 \\
3 \cdot 9\end{array}$ & $\begin{array}{l}\text { Total entry } \\
\text { Head entry } \\
\text { Portal uptake }\end{array}$ & $\begin{array}{r}86 \cdot 5 \\
5 \cdot 5 \\
32 \cdot 0\end{array}$ & $\frac{5 \cdot 6}{2 \cdot 1}$ \\
\hline
\end{tabular}

Methods of calculation of entry are given on p. 254 .

The total entry rates of amino acids given in column 7 of Table 3 have been calculated by dividing the rate of infusion of radioactivity by the mean specific activity of free amino acids in carotid plasma. Dividing the rate of infusion of radioactivity by jugular specific activity gives a higher value, which is equal to total entry plus entry from tissue of the head. Entry from the head is obtained by difference. In the same way, dividing the specific activity of portal amino acids into the rate of infusion of radioactivity gives a value which includes portal absorption from the alimentary canal in addition to total entry. Portal uptake is therefore obtained by difference. Column 8 of Table 3 gives, for each sheep, total entry and portal uptake calculated in the above manner and expressed as $\mathrm{mg}$ amino acid per min per $\mathrm{kg}$ body-weight. 
A regression curve of total amino acid entry $(\mathrm{mg} / \mathrm{min} . \mathrm{kg})$ on daily dietary protein intake $(\mathrm{g} / \mathrm{kg})$ yielded a line described by

$$
Y=2 \cdot 14+\mathrm{I} \cdot 38 X(r=0.878, \quad 0.02>P>0.01) \text {. }
$$

To enable comparison to be made between the results obtained in the present work and those presented previously (Ford \& Reilly, I970) based on values found for specific activity in jugular plasma, the regression of amino acid entry rates on dietary protein

Table 4. Glucose entry rates in sheep used for glucose infusions

\begin{tabular}{|c|c|c|c|c|c|c|c|}
\hline \multirow[b]{3}{*}{$\begin{array}{l}\text { Sheep } \\
\text { no. }\end{array}$} & \multicolumn{4}{|c|}{$\begin{array}{c}\text { Mean specific radioactivity } \\
\text { of glucose }\end{array}$} & \multirow{3}{*}{$\begin{array}{l}\text { Daily crude } \\
\text { protein } \\
\text { intake } \\
\text { (g/kg body- } \\
\text { weight) }\end{array}$} & \multicolumn{2}{|c|}{ Glucose entry rate } \\
\hline & \multicolumn{2}{|c|}{$\left[\mathrm{U}-{ }^{14} \mathrm{C}\right] \mathrm{glucose}$ infusion } & In carotid & In jugular & & & mg glucose/ \\
\hline & $\begin{array}{c}\text { Rate } \\
\text { (nCi/min) }\end{array}$ & $\begin{array}{l}\text { Duration } \\
\text { (min) }\end{array}$ & $\begin{array}{c}\text { plasma } \\
\text { (nCi/mg C) }\end{array}$ & $\begin{array}{c}\text { plasma } \\
(\mathrm{nCi} / \mathrm{mg} \mathrm{C})\end{array}$ & & $\mathrm{mg} \mathrm{C} / \mathrm{min}$ & $\begin{array}{l}\text { min. } k g \text { body- } \\
\text { weight }\end{array}$ \\
\hline 7 & I 96 & 197 & $8 \cdot 4$ & $8 \cdot 3$ & $I \cdot I 6$ & $23 \cdot 2$ & I. 5 \\
\hline 66 & 218 & 181 & $13 \cdot 6$ & $13 \cdot 8$ & $1 \cdot 37$ & $15 \cdot 4$ & $I \cdot I$ \\
\hline 65 & 198 & 172 & 144 & 1477 & $r \cdot 40$ & 13.5 & $x \cdot 07$ \\
\hline 22 & 205 & 194 & $7 \cdot 9$ & $7 \cdot 9$ & $2 \cdot 54$ & $26 \cdot 0$ & $\mathrm{I} \cdot 9$ \\
\hline 64 & 206 & 196 & 6.9 & $7 \cdot 0$ & $2 \cdot 60$ & $29 \cdot 0$ & $2 \cdot 2$ \\
\hline 17 & 206 & 186 & - & $8 \cdot 4$ & $\mathrm{I} \cdot 04$ & 25.0 & $1 \cdot 3$ \\
\hline 263 & 210 & 187 & - & $11 \cdot 7$ & $I \cdot I 6$ & 18.0 & $I \cdot I$ \\
\hline 214 & 208 & 183 & - & $6 \cdot 0$ & $2 \cdot 20$ & $36 \cdot 0$ & $2 \cdot 25$ \\
\hline 260 & I97 & I92 & - & $7 \cdot 0$ & $2 \cdot 70$ & $29 \cdot 0$ & $2 \cdot 25$ \\
\hline
\end{tabular}

Values for sheep nos, I 7, 263, 214 and 260 are taken from Ford \& Reilly (I969).

The method of calculation of entry rates is given on p. 255.

intake was also calculated using the values obtained in the present series of experiments for jugular plasma. This line is described by

$$
Y=2 \cdot 69+\mathrm{I} \cdot 34 X \quad(r=0.87,0.02>P>0.01),
$$

and is to be compared with the line previously described for four other non-pregnant yearling Clun Forest sheep eating similar diets

$$
Y=\mathrm{I} \cdot 29+\mathrm{I} \cdot 204 X \quad(r=0.992, \quad 0.01>P>0.005) .
$$

Analysis of the average residual variance of the regression coefficients for the two groups showed that the slopes were not significantly different, and analysis of the variance of the difference between the intercepts showed that this also was not significant. The two groups of observations may therefore be considered to be samples from the same population.

Table 4 gives glucose entry rates for the five sheep which were infused with $\left[\mathrm{U}-{ }^{14} \mathrm{C}\right]$ glucose. Entry rates of glucose are calculated in the same manner as described for amino acids. It also gives particulars for four other sheep (nos. 17, 263, 214 and 260) given infusions of $\left[\mathrm{U}-{ }^{14} \mathrm{C}\right]$ glucose, which are quoted from Ford \& Reilly (1969). When these nine results are taken together, which is justified in view of the findings described in the previous paragraph, a regression curve of glucose entry on dietary 
protein intake yields a line described by $Y=0.375+0.702 X$ which shows a highly significant correlation between protein intake and glucose entry

$$
(r=0.866,0.005>P>0.001) \text {. }
$$

These results are presented in Fig. I.

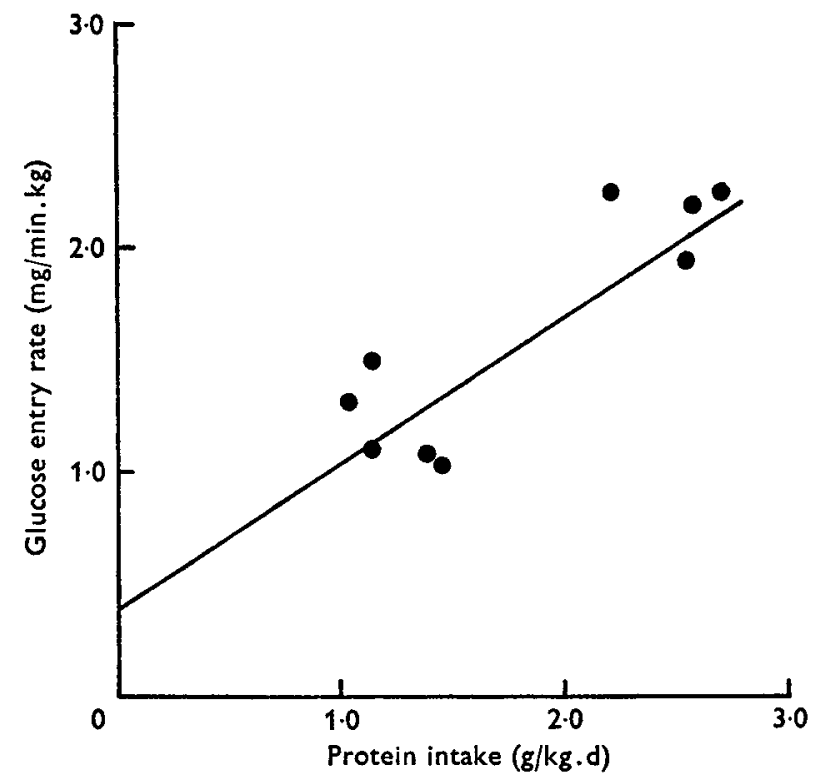

Fig. I. Regression, in sheep, of glucose entry rate $(\mathrm{mg} / \mathrm{min} . \mathrm{kg})$ on daily protein intake $(\mathrm{g} / \mathrm{kg}): Y=0.375+0.702 X(r=0.866,0.005>P>0.001)$.

Table 5. Mean specific activities ( $n C i / m g C)$ of glucose and amino acids in tissues

\begin{tabular}{|c|c|c|c|c|c|c|}
\hline \multirow[b]{2}{*}{ Sheep no. } & \multicolumn{2}{|c|}{ Liver } & \multicolumn{2}{|c|}{ Kidney } & \multicolumn{2}{|c|}{ Muscle } \\
\hline & Amino acids & Glucose & Amino acids & Glucose & Amino acids & Glucose \\
\hline 7 & $4 \cdot 5$ & 0.5 & $6 \cdot 2$ & $2 \cdot 2$ & $x \cdot 0$ & 0.7 \\
\hline 2 & $4 \cdot 0$ & $2 \cdot 8$ & $5 \cdot 8$ & $2 \cdot 5$ & $I \cdot O$ & $I \cdot O$ \\
\hline 66 & $5 \cdot 4$ & $3 \cdot 4$ & $6 \cdot 4$ & $2 \cdot 4$ & $x \cdot 8$ & $2 \cdot 8$ \\
\hline 22 & $4 \cdot 2$ & $2 \cdot 2$ & $6 \cdot 2$ & $2 \cdot 5$ & $I \cdot 2$ & 0.6 \\
\hline 64 & $3 \cdot 3$ & $3 \cdot 5$ & $4 \cdot 3$ & $2 \cdot I$ & $I \cdot O$ & - \\
\hline
\end{tabular}

The proportions of glucose derived from amino acids, which are given in the last two columns of Table 6 are calculated from the pairs of values shown for liver and kidney samples in this table.

All values are the means of three or more determinations.

Table 5 gives the specific activities of glucose and amino acids in the samples of liver, kidney and skeletal muscle which were removed and frozen in liquid nitrogen immediately upon completion of the infusion of $\left[\mathrm{U}-{ }^{14} \mathrm{C}\right]$-labelled mixed amino acids. Fig. 2 shows the ratios (expressed as percentages) of the specific activities of amino acids in liver and kidney to those in carotid plasma after various periods of infusion.

Table 6 gives the results of different calculations of the proportion of glucose 
derived from amino acids. The basis for the various calculations and the possible significance of the results is considered in the discussion. Fig. 3 shows the regression of portal absorption of amino acids $(\mathrm{mg} / \mathrm{min} . \mathrm{kg})$ on daily dietary protein intake $(\mathrm{g} / \mathrm{kg})$.

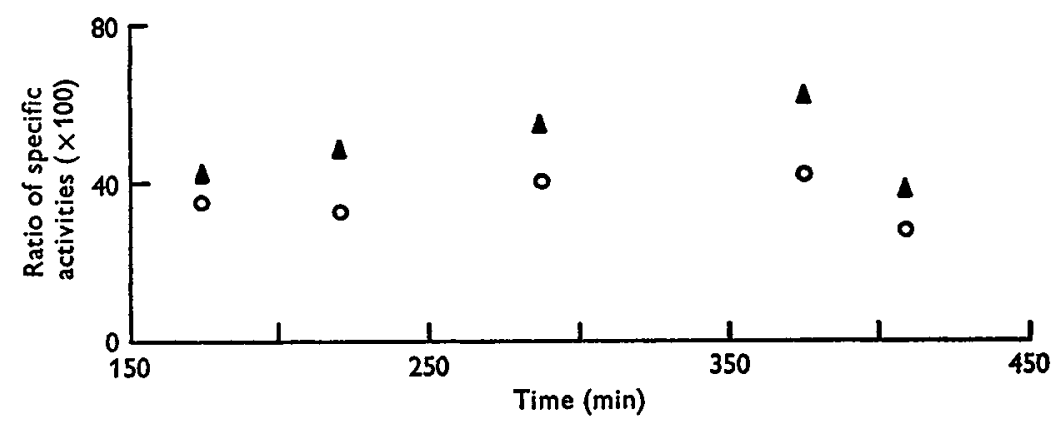

Fig. 2. Relationships between the specific activities of amino acids in liver and kidney samples to those in carotid plasma samples from sheep after various periods of infusion of [U-14 $\mathrm{C}$ ]labelled mixed amino acids.

$$
\begin{aligned}
& \Delta, \text { ratio, } \frac{\text { specific activity of kidney amino acids }}{\text { specific activity of plasma amino acids }} \times 100 ; \\
& O, \text { ratio, } \frac{\text { specific activity of liver amino acids }}{\text { specific activity of plasma amino acids }} \times 100 .
\end{aligned}
$$

Table 6. Proportions of glucose derived from amino acids

\begin{tabular}{|c|c|c|c|c|c|}
\hline & & & $\left(x_{100}\right)$ & & \\
\hline Sheep no. & $\mathbf{J}$ & A & $\mathbf{P}$ & $\mathbf{L}$ & $\mathbf{K}$ \\
\hline 63 & $35^{\circ} \circ$ & $33 \cdot 0$ & $44^{\circ} \circ$ & - & - \\
\hline 7 & 13.0 & II' 5 & I $8 \cdot 0$ & II.O & $33 \cdot 8$ \\
\hline 2 & $24 \%$ & $2 \mathrm{I} \cdot 5$ & 29.0 & $70 \cdot 0$ & $43 \cdot 0$ \\
\hline 66 & $25 \cdot 0$ & 24.0 & $36 \cdot 0$ & $62 \cdot 0$ & $44^{\circ} \circ$ \\
\hline 22 & $3 \mathrm{I} \cdot 5$ & $29^{\circ} 0$ & $39 \cdot 0$ & $53 \cdot 0$ & $40 \cdot 0$ \\
\hline 64 & $5 I \cdot 0$ & $49^{\circ} \circ$ & $68 \cdot 0$ & 106.0 & $49 \cdot 0$ \\
\hline $\begin{array}{l}\text { Mean pro- } \\
\text { portions of } \\
\text { glucose de- } \\
\text { rived from } \\
\text { amino acids }\end{array}$ & & & & & \\
\hline$\pm \mathrm{SEM}$ & $30 \cdot 0 \pm 5 \cdot 2(6)$ & $28 \cdot 2 \pm 5 \cdot 1(6)$ & $39 \cdot 16 \pm 6 \cdot 9(6)$ & $72 \cdot 75 \pm 11 \cdot 6(5)$ & $4 \mathrm{I} \cdot 3 \pm \mathrm{I} \cdot 9(5)$ \\
\hline
\end{tabular}

Ratios of specific activities of glucose to amino acids

$\mathrm{J}, \mathrm{A}, \mathrm{P}, \mathrm{L}$ and $\mathrm{K}$ are ratios of specific activities of glucose to amino acid in jugular, arterial and portal plasma and in liver and kidney tissue respectively.

The line is described by $Y=0.58+0.58 X$ and shows a significant correlation between protein intake and amino acid absorption $(r=0.884,0.02>P>0.01)$.

The rates of production of glucose from amino acids have been calculated from the values for percentage glucose derived from amino acids (Table 6, column 2) and glucose entry rates calculated from specific activity values of glucose in jugular plasma (Table 4). The regression of glucose production from amino acids on amino 
acid entry rates has been calculated and yields the line $Y=0.189 X-0.414$, and shows a significant correlation $(r=0.84,0.01>P>0.005)$. These results are given in Fig. 4.

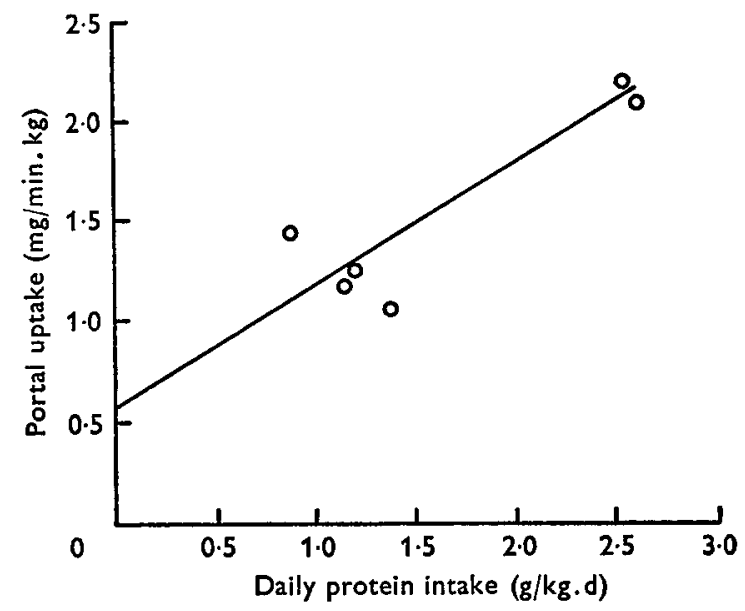

Fig. 3. Regression of portal uptake of amino acids $(\mathrm{mg} / \mathrm{min} . \mathrm{kg})$ on daily protein intake $(\mathrm{g} / \mathrm{kg})$ of sheep: $Y=0.58+0.58 X(r=0.884,0.02>P>0.01)$.

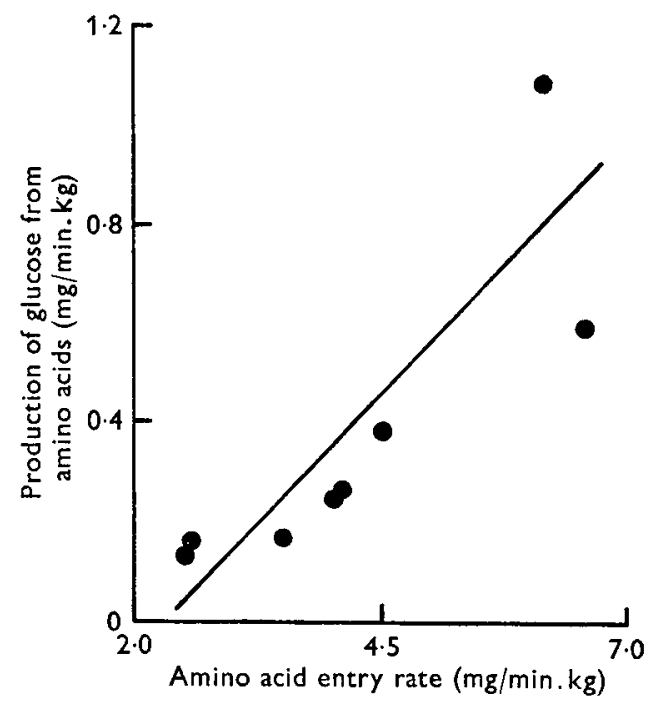

Fig. 4. Regression of production of glucose from amino acids ( $\mathrm{mg} / \mathrm{min} . \mathrm{kg}$ ) on amino acid entry rate $(\mathrm{mg} / \mathrm{min} . \mathrm{kg}): Y=0.189 X-0.414(r=0.84,0.01>P>0.005)$.

\section{DISCUSSION}

Calculation of entry rates

In previous experiments (Ford \& Reilly, 1969, 1970) we calculated, from the specific activities of jugular amino acid, amino acid entry rates for non-pregnant sheep on diets supplying different amounts of protein and for pregnant sheep eating a diet supplying protein within the range eaten by the non-pregnant animals. The present 
investigation has shown that calculations made on the basis of specific activities of amino acids in samples of jugular plasma yield results which are too high. This is because entry of unlabelled amino acids from the head and neck tissues causes the specific activity in jugular plasma to be lower than in mixed venous plasma. The best accessible source which is most nearly representative of this is carotid plasma. It is possible that previous estimates of entry rates of other metabolites, e.g. acetate (Lindsay \& Ford, 1964) and free fatty acids (Leat \& Ford, 1966), are also artificially high for the same reason.

We have also compared specific activity of glucose in jugular and carotid plasma during continuous infusions of [U-14 $\mathrm{C}]$ glucose and found no measurable difference (Table 4). Previous reports of glucose entry rates based on jugular plasma (Annison \& White, I96r; Ford, 1963; Bergman, 1963), therefore, remain valid. Furthermore, we have found that the specific activity of glucose in portal plasma during glucose entry measurements is very similar to glucose specific activity in jugular and carotid plasma (column 5, Table 3). This finding is consistent with the fact that ruminants absorb only negligible quantities of glucose from the alimentary canal (Lindsay, 1959). However, the present experiments confirm that appreciable quantities of amino acids are absorbed from the gut in ruminants and the amounts have been measured. Fig. 3 shows a significant correlation between portal uptake and daily crude protein intake. The mean ratio of the rate of portal absorption of amino acids to total amino acid production rate in these experiments is $33.5 \pm 1.8 \%$ (six animals).

Clearly it would be possible to measure the portal uptake of metabolites such as short-chain fatty acids by measuring specific activity in carotid and portal plasma as we have done for amino acids in the present work.

The significant correlation between daily dietary protein intake $(\mathrm{g} / \mathrm{kg})$ and total glucose entry rate (mg/min. kg) (Fig. I) confirms the findings of Ford (1965).

\section{Production of glucose from amino acids}

The proportion of glucose derived from amino acids was previously calculated (Ford \& Reilly, 1969, 1970) by comparing specific radioactivities of glucose with those of amino acids in jugular plasma. We considered that the specific activities would be identical if all glucose was derived from plasma amino acids and a proportionally lower glucose specific activity would indicate what proportion of glucose was derived from amino acids. The validity of the use of uniformly labelled mixed amino acids for this purpose was considered in one of the earlier papers (Ford \& Reilly, 1969). A value has been calculated on this basis from the results of the present experiments and is given in the second column of Table 6.

Values calculated from arterial plasma (column 3 , Table 6) are slightly lower and values based on portal plasma (column 4) are slightly higher. However, it seemed likely that, because gluconeogenesis takes place in tissues and not in the plasma, the specific activities of tissue amino acid and glucose would be the most accurate basis for calculations. The last two columns of Table 6 give percentages derived from tissue specific activities, for liver and kidney respectively. Without a knowledge of the proportion of total synthesized glucose originating in each tissue, it 
is not possible to calculate a total percentage from the values for liver and kidney but in most instances the percentage value for liver is greater than the values derived from plasma specific activities. The exception is sheep 7 in which the percentage value for liver was I I, but all three values calculated from plasma were also low. The high value for liver of sheep 64 is also reflected in high values calculated from plasma.

Fig. 4 shows that the relationship betwen the amount of glucose produced from amino acids and the rate of amino acid production is the same in both series of experiments. However, the percentage of glucose derived from amino acids is different in the two series. In the earlier series the mean percentage for four sheep was $I_{4}$ and, on the same basis, in the present series the mean percentage is 30 for the four sheep for which complete results are available (nos. 7, 22, 64 and 66, Table 6).

Comparison of percentages is often misleading, especially if the basis taken as $100 \%$ is not the same. In this instance, the basis is total glucose production by two different groups of four sheep. It is therefore better to compare actual rates of glucose production from amino acids after adjustment for body-weight differences. When this is done for the four sheep in the present series two of them, nos. 7 and 66 produced glucose from amino acids at rates of 0.19 and $0.27 \mathrm{mg} / \mathrm{min} . \mathrm{kg}$ respectively. These figures are of the same order as the mean rate of $0.24 \mathrm{mg} / \mathrm{min} . \mathrm{kg}$ in the earlier series of four sheep.

However, the two other sheep, nos. 22 and 64 , on the high-protein diet produced glucose from amino acids at rates of 0.59 and $\mathrm{I} \cdot \mathrm{I} \mathrm{mg} / \mathrm{min} . \mathrm{kg}$. These high rates become especially high when expressed as percentages of glucose entry rates which at $\mathrm{r} \cdot 9$ and $2 \cdot 2 \mathrm{mg} / \mathrm{min} . \mathrm{kg}$ were relatively low for sheep on a high-protein diet.

\section{Production of glucose from other substrates}

Glycerol has been shown to be the origin of about $5 \%$ of total glucose energy in fed sheep rising to about $23 \%$ during starvation (Bergman, Starr \& Reulein, 1968).

Leng et al. (1967) found that $54 \%$ of glucose was derived from propionate produced in the rumen whilst Bergman et al. (1966) had shown that about $27 \%$ of glucose originated from propionate which had been absorbed. The difference was due to the conversion of appreciable quantities of propionate into lactate in the rumen wall. Annison, Lindsay \& White ( $\mathrm{I} \mathrm{g}_{3}$ ) showed that about $20 \%$ of glucose was derived from lactate. Some of the lactate would be produced by rumen fermentation, some from propionate in the rumen wall and the remainder by recycling from glucose.

A proportion of synthesized glucose remains to be accounted for and it is likely that this will be derived from amino acids. Estimates of the contribution by protein have been based on the excretion of urea nitrogen. In this way Bergman et al. (1966) postulated a potential production of $57 \mathrm{~g} / \mathrm{d}$ on a daily intake of crude protein which was about twice that received by two sheep in our previous study and which produced approximately $26 \mathrm{~g} / \mathrm{d}$ of glucose from amino acids.

\section{Tissue and plasma amino acid specific activities}

Comparison of the tissue specific activities in Table 5 and plasma specific activities in columns 4 and 5 of Table 3 shows that, though in many instances glucose specific 
activity in liver approaches that in portal plasma, amino acid specific activity is always appreciably lower than in portal plasma. Fig. 2 shows that the proportion does not alter appreciably over a period of $6 \cdot 75 \mathrm{~h}$.

This finding corroborates the results obtained by Loftfield \& Harris (1956). These authors found that, in rats, the specific activity of $\mathrm{L}-\left[{ }^{14} \mathrm{C}\right]$ leucine in liver only attained $40 \%$ of the injected dose even after repeated injections every $10 \mathrm{~min}$ for $80 \mathrm{~min}$. They also found that the continuous infusion of large quantities of unlabelled Lleucine for $3 \mathrm{~d}$ into rats that had been previously given a single injection of $\mathrm{L}-\left[{ }^{44} \mathrm{C}\right]-$ leucine of high specific activity only reduced the liver leucine specific activity by onehalf. At the end of infusions of L- $\left[\mathrm{U}_{-}{ }^{14} \mathrm{C}\right] \mathrm{lysine}$ into rats, Waterlow \& Stephen (r968) found that the mean ratio of specific activity of lysine in liver to specific activity of lysine in plasma was 0.67 . They found a higher ratio than this for muscle, whereas Garlick (1969) found that the specific activity of glycine was higher in liver than in muscle.

Table 7. Concentrations of free amino acids in plasma and tissues of the cat and rat. The figures are summations of values of individual amino acids given in each of the papers quoted

\begin{tabular}{|c|c|c|c|c|}
\hline Reference & $\begin{array}{c}\text { Plasma } \\
(\mathrm{mg} / \mathrm{ro0} \mathrm{ml})\end{array}$ & $\begin{array}{c}\text { Liver } \\
(\mathrm{mg} / \mathrm{r} 00 \mathrm{~g})\end{array}$ & $\begin{array}{c}\text { Muscle } \\
\text { (mg/100 g) }\end{array}$ & $\begin{array}{c}\text { Kidney } \\
(\mathrm{mg} / \mathrm{r} 00 \mathrm{~g})\end{array}$ \\
\hline Tallan et al. (1954) (cat) & $29 \cdot 6$ & $142 \cdot 6$ & $106 \cdot 2$ & 217.7 \\
\hline Solomon et al. (r95I) (rat) & - & 124.7 & $45 \cdot 7$ & 203.5 \\
\hline $\begin{array}{l}\text { Schurr, Thompson, Hen- } \\
\text { derson \& Elvehjem (1950) } \\
\text { (rat) }\end{array}$ & $23 \cdot 0$ & 65.9 & $6 r \cdot 4$ & - \\
\hline Schurr, Thompson, Hen- & $3 I \cdot 6$ & $66 \cdot r$ & $66 \cdot 5$ & - \\
\hline
\end{tabular}

These two sets of results indicate that there is marked compartmentation of the amino acid pool in rats. There is much additional evidence that this is so: for example, Schurr, Thompson, Henderson \& Elvehjem (1950) and Schurr, Thompson, Henderson, Williams \& Elvehjem (1950) compared the concentrations of free amino acids in plasma with those in various tissues in rats, and Solomon, Johnson, Sheffner \& Bergeim (r951) compared tissue concentrations of free amino acids in the same species. Tallan, Moore \& Stein (1954) compared the values in samples of plasma and tissues in cats. Table 7 shows values calculated from these various reports. Notwithstanding the large differences between values for liver free amino acids of rats obtained by Solomon et al. (r95I) and by Schurr, Thompson, Henderson, \& Elvehjem (r950) and Schurr, Thompson, Henderson, Williams \& Elvehjem (1950), it is quite apparent that in all tissues studied the concentrations of free amino acids are considerably higher than in plasma samples. The values quoted in Table 2 for amino acids in tissues yield mean values of $234.9 \pm 9.05(6) \mathrm{mg} / \mathrm{x} 00 \mathrm{~g}$ for liver, $295.8 \pm 9.5(6)$ for kidney and $17 \mathrm{I} \cdot 0 \pm 8 \cdot 2(6)$ for muscle. A ratio of $6: \mathrm{I}$ is obtained for total free amino acids in liver compared to jugular plasma. Waterlow \& Stephen (I966) obtained a ratio of I I: I for total $\alpha$-amino nitrogen in liver compared to total $\alpha$-amino nitrogen in plasma of rats, whereas Tallan et al. (1954) found a value of $4 \cdot 8: \mathrm{I}$ in cats when they compared 
total amino acid concentrations in liver and plasma. These results agree well with earlier work by Awapara \& Marvin (1949) and Freidberg \& Greenberg (1947) and with later work by Coulson \& Hernandez (1968), all of whom showed that liver and kidney are active in taking up amino acids from plasma and concentrating them. Kidney showed this characteristic most markedly, liver to a less extent and muscle to a still lesser extent. These findings agree with the results shown in Table 2 where concentrations of free amino acids in tissues are seen to follow this pattern.

From these collected observations it is apparent that the major compartments of the free amino acid pool are not in rapid equilibrium, and that the pool is not homogeneous.

We consider that there are two major reservations to be made regarding the calculations of transfer rates of carbon from amino acids to glucose in the intact animal, made from specific activities of amino acids and glucose in tissues. One is the lack of information on the proportions of glucose synthesized in individual glucogenic tissues; without this information it is not possible to obtain a meaningful value for the proportion of total glucose production arising from amino acids. The other arises from the differences in relationships between the specific activities of amino acids in plasma and in the tissues which produce glucose (Table 5). In view of these reservations, rates of production of amino acids from glucose would best be obtained by using continuous infusions of single uniformly labelled amino acids coupled with determinations of flow-rates through glucose-synthesizing tissues.

The authors wish to thank the Agricultural Research Council for financial support and Miss J. Evans and Mrs J. Goodfellow for technical help.

\section{REFERENCES}

Annison, E. F., Brown, R. E., Leng, R. A., Lindsay, D. B. \& West, C. E. (r967). Biochem. f. 104, 135. Annison, E. F., Lindsay, D. B. \& White, R. R. (1963). Biochem. F. 88, 243.

Annison, E. F. \& White, R. R. (196I). Biochem. F. 80, 162.

Awapara, J. \& Marvin, H. N. (1949). J. biol. Chem. x78, 69г.

Bergman, E. N. (1963). Am. Y. Physiol. 204, 147.

Bergman, E. N., Roe, W. E. \& Kon, K. (1966). Am. F. Physiol. 211, 793.

Bergman, E. N., Starr, D. J. \& Reulein, S. S. (r 968). Am. F. Physiol. 215, 874.

Coulson, R. A. \& Hernandez, T. (1968). Am. F. Physiol. 215, 741.

Ford, E. J. H. (1963). Biochem. F. 88, 427.

Ford, E. J. H. (1965). F. agric. Sci., Camb. 65, 4 I.

Ford, E. J. H. \& Reilly, P. E. B. (1969). Res. vet. Sci. xo, 409.

Ford, E. J. H. \& Reilly, P. E. B. (1970). Res. vet. Sci. II, 575.

Friedberg, F. \& Greenberg, D. M. (r947). F. biol. Chem. I68, 4I r.

Garlick, P. J. (1969). Nature, Lond. 223, 6r.

Hall, T. C. \& Cocking, E. C. (1965). Biochem. F. 96, 626.

Harris, C. K., Tigane, E. \& Hanes, C. S. (I96I). Can. F. Biochem. Physiol. 39, 439.

Huggett, A. St. G. \& Nixon, D. A. (I957). Lancet ii, 368.

Jones, G. B. (1965). Analyt. Biochem. 12, 249.

Krebs, H. A. (1964). Proc. R. Soc. B r59, 545.

Leat, W. M. F. \& Ford, E. J. H. (1966). Biochem. F. Ior, 3 I 7.

Leibholz, J. (1965). Aust. F. agric. Res. 16, 973.

Leng, R. A., Steele, J. W. \& Luick, J. R. (1967). Biochem. F. 103, 785.

Lindsay, D. B. (1959). Vet. Revs Annot. 5, ro3.

Lindsay, D. B. \& Ford, E. J. H. (1964). Biochem. F. go, 24. 
Loftfield, R. B. \& Harris, A. (1956). F. biol. Chem. 219, I 5 I.

Rosen, H. (1957). Archs Biochem. Biophys. 67, 10.

Schurr, P. E., Thompson, H. T., Henderson, L. M. \& Elvehjem, C. A. (ı950). F. biol. Chem. x82, 29.

Schurr, P. E., Thompson, H. T., Henderson, L. M., Williams, J. N. Jr. \& Elvehjem, C. A. (1950). f. biol. Chem. I82, 39.

Slater, J. S. (1965). Res, vet. Sci. 6, 92.

Solomon, J. D., Johnson, C. A., Sheffner, A. L. \& Bergeim, O. (1951). F. biol. Chem. 189, 629.

Steele, R., Wall, J. S., de Bodo, R. C. \& Altszuler, N. (1956). Am. F. Physiol. r87, I 5.

Tallan, H. H., Moore, S. \& Stein, W. H. (1954). F. biol. Chem. 211, 927.

Waterlow, J. C. \& Stephen, J. M. L. (1966). Br. F. Nutr. 20, 46r.

Waterlow, J. C. \& Stephen, J. M. L. (1968). Clin. Sci. 35, 287. 